\title{
Dairy Farming and the Stagnated Biogas Use in Rungwe District, Tanzania: An Investigation of the Constraining Factors
}

\author{
Agnes Godfrey Mwakaje \\ Institute of Resource Assessment, University of Dar es Salaam,
}

Tanzania

\section{Introduction}

Dairy farming plays a key role in the lives of poor, rural people in developing countries, providing a major proportion of their cash income, capital assets, draught power, fuel and fertilizer. Small-scale dairying produces valuable food products and provides a regular income and work. Dairying also provides much of the cash needed to perform other socioeconomic activities. Milk production generates reliable incomes to meet household livelihoods (Somda et al., 2005). Possession of dairy animals means also financial security, status, self-confidence and an opportunity to have some control over their live (Ramkumar, 2004). It is also more labour intensive and supports substantial employment in production, processing and marketing. This is partly because dairy production often require the introduction of specialised dairy breeds and increased levels of inputs (nutrition and health care) and good linkages to markets, both for milk sales and input acquisition. In Kenya dairy farming has become a very significant source of income and food for an estimated 625,000 smallholder producer households and for those involved in the marketing of milk, in total some $25 \%$ of all households in Kenya benefit from dairy farming (Muriuki et al., 2001). In Tanzania about 700000 dairy cattle are available under smallholder farmers, with an average of 4 cows per household, there might be 175 households keeping indoor fed dairy cattle in Tanzania. Dairy farming in Tanzania is estimated to grow at a rate of $6 \%$ per year and there are about 190,000 registered farmers currently (Swai and Kurimuribo, 2011). Most of these cattle are kept in the highland and relatively cold regions of Arusha, Mbeya, Kagera, Iringa and Morogoro. Smallholder dairy farming in Tanzania has had a significant impact on poverty alleviation in terms of income, education, food security and stabilizing farm incomes (Kisusu et al., 2000).

On the other hand, dairy manure is potential for biogas generation. Dairy manure biogas digester technology has proven to be technically and economically feasible and successful in many applications (Schwengels, 2009). Technology pathways involving biogas, natural gas or electricity are advantageous (Hedegaard et al 2008) for rural development. Empirical evidence suggests that each household can realise up to US\$ 724 by replacing wood use with biogas, apart from other positive impacts to the environment (Langeni et al., 2010). A study by the Institute of Resource Assessment (IRA), University of Dar es Salaam, in 2005, shows a reduction of firewood consumption from 700 to $145 \mathrm{~m}^{3}$ for Lomwe Secondary 
School following the adoption of biogas technology which meant a reduction Energy saved annually is approximately 6.7 Terra Joules (T.J) (a reduction of 78.9\%) of $\mathrm{CO}^{2}$ annually (IRA, 2005).

\section{Biogas development trend in Tanzania}

Biogas technology utilizing animal waste is not new in Tanzania; it was introduced in the country as early as the 1950s by private stakeholders. In 1975, the government through the Small Industries Development Organisation (SIDO) introduced the Indian design (floating gasholder digester) in primary and secondary schools, rural health centres and a number of other institutions. In 1982, the Parastatal Organization Centre for Agricultural Mechanization and Rural Technology (CAMARTEC) increased the dissemination of this technology in the northern regions. About 1 year later, that is around 1983, technical cooperation between Tanzania and the Federal Republic of Germany led to the introduction of the Biogas Extension Services (BES). CAMARTEC and the Deutsche Gesellschaft fur Technische Zusammenarbeit (GTZ) were in-charge of implementing this project and the latter seconded an interdisciplinary team of social scientists, mechanical engineers and agriculturists to Tanzania (Sasse et al., 1991). Between 1984-1985 more strategies were developed to boost biogas adoption. Household plants were offered with a digester volume of 8,12 and $16 \mathrm{~m}^{3}$, and in 1990 the programme comprised standardized plants of sizes 12, 16, 30 and $50 \mathrm{~m}^{3}$ for households and institutions (Mwakaje, 2008). The development work towards sustainable reliability and user friendliness resulted in extensive integration of biogas plants into the work routines of farmers. Over the period, CAMARTEC were involved in building capacity by training technicians in biogas plant construction. A "biogas unit" scheme was introduced and this integrated biogas plants, livestock housing with a concrete floor (Mwakaje, 2008). CAMARTEC was also providing advice on the utilization of slurry, gas pipeline systems, burners and lamps; and women were specifically instructed on how to use and manage the plants. The Ministry of Energy and Minerals in collaboration with donors was also promoting biogas use in the Dar es Salaam region. Its main activity was to support the dissemination of biogas technology in the region through facilitating training for private craftsmen, built demonstration plants and undertaking monitoring and evaluation. Up to 1989, only 200 units of biogas had been installed all over the country (Sasse et al., 1991) but in 1992 this had increased to 600 plants national-wide. Nevertheless, as Mwakaje (2008) noted despite all the efforts, the biogas technology did not diffuse much to the rural poor communities in many parts of the country where indoor fed dairy cattle are kept. Reasons for this poor diffusion of the biogas technology included high installation and maintenance costs and inadequate awareness about the technology. The conventional units being built in the country were large and expensive, costing approximately US $\$ 1400$ for one unit (Rutamu, 1991) to USD 2200 depending on the size of digester (IRA, 2005). Furthermore, repair and maintenance required highly skilled labour and most component parts, constructed mainly from concrete and steel, were far out of the financial reach of smallholder farmers (Mwakaje, 2008). This slow pace of biogas technology development by CAMARTEC raised a number of criticisms among stakeholders. For example, the Evangelical Lutheran Church of Tanzania (ELCT) blamed CAMARTEC its commercially oriented and strictly standardized dissemination programme. The ELCT claimed that the programme had not been adapted to Tanzanian conditions as it only served the rich farmers (Sasse et al., 1991). But also most of the CAMATERC activities were concentrated mainly in 
the two regions of Kilimanjaro and Arusha in a country with more than 20 regions. On the other hand, the Ministry of energy and minerals' activities were concentrated in the Dar es Salaam region where unfortunately indoor fed dairy cattle are limited to a few households.

Reacting to some of these criticisms, the government of Tanzania changed the biogas technology dissemination strategy in the country. In the years starting 2000 polythene tubular digesters were promoted to reduce production cost through using local materials and simplified installation and operation costs (Mwakaje, 2008). The type of plastic needed for polythene was locally manufactured in Tanzania, maintenance and repair were simple, cheap, and did not require skilled labour and the cost of construction was low. A model promoted by the Sustainable Rural Development (SURUDE) was a low-cost design suitable for poor farmers (CEBITEC, 2003) in rural areas. The material cost was about US\$ 100. However, this type of biodigester had one major disadvantage in that it could be easily sabotaged (torn out). This is because the plastic materials of the biodigestor are normally placed on the surface outside the house and therefore could easily be destroyed (Mwakaje 2008).

\subsection{Dairy sector and biogas use in Rungwe district}

Rungwe district lies between latitudes $8030 \mathrm{E}$ and $9030 \mathrm{E}$ and longitudes $33{ }^{\circ} \mathrm{S}$ and $34^{\circ} \mathrm{S}$. It is one of the six districts of Mbeya Region, located in the Southern Highlands of Tanzania. The other districts are Kyela, Chunya, Ileje, Mbeya Rural and Mbozi. Rungwe district has a total area of 2211 sq. $\mathrm{km}$ of which $75 \%$ is arable land (URT, 1997). Of the remaining area, $44.5 \mathrm{sq}$. $\mathrm{km}$ is covered by forest while $498.3 \mathrm{sq} . \mathrm{km}$ is either mountainous or residential areas.

The district is one of the densely populated districts in Tanzania (URT, 2002) with a population of 307,270 , which is equivalent to 139 persons per square kilometre with an annual growth rate of $0.9 \%$ (URT 2010). The district has limited natural vegetation which varies from upper montane forest at higher elevations to the wet woodland (Miombo) at lower elevations. Forestry reserve accounts for $43,749.9$ ha and other forests about 65,813 ha (URT, 2008). In recent years, much of this natural vegetation has been cleared/transformed for agriculture, for habitation, and firewood. Most of the remaining natural vegetation is found in government forest reserves and in locally protected areas, though even these areas have been subjected to varying degrees of people driven disturbances.

Rungwe district put great importance to livestock development particularly dairy cattle as one of the major economic activities. In 2005 the district had 26,137 indoor fed dairy cattle with milk production estimated to be $41,000,000$ litres per year. The district has 74,450 households and almost half of the households keep some cattle or pigs in their homestead with an average of between 2-6 cattle (Mwakaje, 2008). Smallholder dairy production is an important undertaking and, if adequately supported by appropriate policies and adaptive research technologies, it may contribute significantly towards the household economy, selfsufficiency in milk and national gross domestic product (Swai and Kimambo, 2011). Walshe et al (1991) comments that where there is access to a market, dairying is preferred to meat production since it makes more efficient use of feed resources and provides a regular income to the producer.

Promotion of smallholder dairy farming can solve the problem of rural poor accessing to clean energy like biogas. 
The district is also famous for keeping pigs. Rungwe district has about 44,334 pigs which also contribute significantly to the household's economy and nutrition.

Studies in several African countries, provides a rough sense of the likely economics of introducing biodigesters (Schwengels, 2009) where 2 cows or 1 cow and other livestock like pigs can be appropriate for a family to meet the need of cooking biogas while other research findings suggest that farming households, having 2 (zero-grazed) to 10 cattle or 8 to 40 pigs (or a combination) are enough to produce gas for a household. This means that available number of indoor fed dairy cattle of more than 26,000 and over 44000 pigs, the district can have the capacity of having more than 20000 biodigester, this is about $27 \%$ of the district's households.

However, despite the high level of indoor fed dairy cattle in Rungwe District and the potential to generate biogas as well as the efforts to promote biogas use in the country since 1970s by the government and donors, biogas technology has not well developed in the district to date. The trend of biogas technology in the district shows that the technology started in 1993 when one person adopted installed a biogas plant (Mwakaje, 2008). In 1996, 12 households got the service by contributing half of the cost. This was a pilot project by the Danish Volunteers that intended to raise awareness of the technology. With the exception of the year 1996, adoption of the biogas technology has remained low and more or less declining (URT, 2005). Up to 2007 there were about 100 biogas plants, an equivalent to only $0.13 \%$ of the total households in the district. This is even more surprising as the district has limited fuelwood sources as well as other clean energy sources. Available information shows that the district has a demand of cooking energy of $600,000 \mathrm{~m}^{3}$ per annum, while the capability to supply is about $400,000 \mathrm{~m}^{3}$ (URT, 2005), a 33\% deficit (Mwakaje, 2008). The scarcity of fuelwood has increased its cost in terms of purchasing price and time used for fetching (Mwakaje, 2008). The use of other clean energy like electricity and solar power is limited due to both cost and reliability (Mwakaje, 2008).

Why the pace of biogas adoption and use in the district has remained stagnant is the main interest of this study. Although, a study by Mwakaje (2008) highlighted some of the constraining factors, it was not exhaustive. The study focused more on the environmental benefits of adopting biogas technology while other equally important issues related to biogas use and adoption such as socio-economic, institutions; awareness as well as policies were not adequately explained. The main objective of the chapter was to come up with an understanding of the reasons for the stagnated biogas use in Rungwe district despite the availability of large number of dairy cattle and other livestock and in an area with highly inadequate fuelwood supply. Specifically, the chapter investigated issues relates to investment costs, expertise availability, role of institutions and policies in influencing biogas use and level of awareness of biogas use among the Rungwe dwellers. Findings from this study will add to the body of knowledge, inform policy makers, donors, service providers, environmentalists and researchers.

\section{Methods}

Data were collected from both primary and secondary sources. Secondary data were collected through literature review using published documents and internet material. There was also a review of policies related to energy in Tanzania. Secondary data helped to establish what has been done in the subject and to read what were the remained gaps for field work were. Institutions supporting biogas development were consulted for 
understanding their performance and constraining factors they are facing. Primary data were collected in areas related to investment cost, awareness, household energy demand, technology service providers, and expertise. In addition, there were consultations with service providers to get information on cost, demand as well as factors constraining the spread of the biogas technology in the District. Furthermore, there was a consultation with local and district institutions and authorities for detailed information on biogas use in the district and whether there has been any efforts to facilitate the adoption of biogas.

The sample frame for this study involved respondents with dairy cattle/biogas use and those with dairy cattle but have not installed biogas plants. Also respondents with access to electricity and other clean energy sources such as LPG were included in the sample. A total of 3 villages were selected for the household sample. These were Isagilo, Kyimo and Mpandapanda. The selection of the villages based on the availability of dairy cows, adoption of biogas technology, availability of other energy sources, socio-economic status and accessibility. The households were selected purposively for those with biogas as well as those with access to electricity as they are few but random for the rest of the dairy keepers.

The total number of households (n) to be surveyed was estimated using the formula below:

$$
\mathrm{n}=\frac{\mathrm{N}}{1+\mathrm{Ne}^{2}}
$$

$\begin{array}{rll}\text { Where: } \mathrm{n} & = & \text { sample size between } 5 \text { and } 10 \% \\ \mathrm{~N} & = & \text { total number of households in the village; and } \\ \mathrm{e} & = & \text { desired margin of error. }\end{array}$

A sample size of about $10 \%$ was selected making a total sample of 120 households. Out of this, 35 had biogas facilities and the remaining 85 had dairy cattle without biogas facility (Table 1). Village roster were used to select the sample households. Data were collected using structured and semi-structured questionnaires and analysed using Statistical Package for Social Sciences (SPSS) as well as livelihoods models. Results have been presented in tables and figures.

\begin{tabular}{|c|c|c|c|c|c|}
\hline Village & Characteristics & $\begin{array}{l}\text { HH With } \\
\text { biogas }\end{array}$ & $\begin{array}{l}\text { HH with } \\
\text { biogas } \\
\text { selected for } \\
\text { interview }\end{array}$ & $\begin{array}{l}\text { HH without } \\
\text { biogas } \\
\text { selected for } \\
\text { interview }\end{array}$ & $\begin{array}{l}\text { Total } \\
\text { Sample } \\
\text { selected }\end{array}$ \\
\hline Isagilo & $\begin{array}{l}\text { Biogas project started free of } \\
\text { charge in } 1996 \text { and } 12 \mathrm{HH} \\
\text { installed biogas plants }\end{array}$ & 22 & 19 & 25 & 43 \\
\hline Kyimo & $\begin{array}{l}\text { Large population of dairy } \\
\text { cows and have electricity } \\
\text { services }\end{array}$ & 13 & 11 & 22 & 30 \\
\hline Mpandapanda & $\begin{array}{l}\text { Large population of dairy } \\
\text { cattle but limited number of } \\
\text { biogas users. }\end{array}$ & 7 & 5 & 22 & 27 \\
\hline Total & & 42 & 35 & 85 & 120 \\
\hline
\end{tabular}

Table 1. Village Characteristics and Sample Size (households) 


\section{Results and discussion}

\subsection{Wealth ranking of the respondents}

To establish the socio-economic profile of the respondents a wealth ranking approach was used. Wealth ranking was important in this study to determine whether there is any relationship between biogas technology adoption and wealth of the household into wealth ranks using a set of pre-established criteria (Afonja, 1992). Since its introduction in the 1980's, rapid rural appraisal (RRA) wealth ranking has become an increasingly accepted means of assessing relative socio-economic status in the context of applied research projects and development programs (Chambers, 1994). In this study the members of village governments were involved in wealth ranking for their respective villagers. Criteria for wealth ranking was adopted as perceived locally it included aspects of, food security, livestock, dairy cattle and other assets ownership, land and annual incomes (Table 2). Results from wealth ranking (based on communities perception) show that there were no people who were really well off in the sample of households but only the so called slightly well-off. Out of the 120 respondents $22 \%$ were slightly well-off while less poor and poor were $55 \%$ and $27 \%$ respectively (Table 2).

\begin{tabular}{|c|c|c|c|}
\hline & Slightly Well-Off & Less Poor & The Poor \\
\hline Food security & $\begin{array}{c}\text { Generally food } \\
\text { secure all the time }\end{array}$ & $\begin{array}{l}\text { Only rarely may } \\
\text { experience seasonal } \\
\text { food insecurity }\end{array}$ & $\begin{array}{l}\text { Experience food insecurity for about } \\
22 \text { months a year }\end{array}$ \\
\hline Assets & $\begin{array}{c}\text { Many own various } \\
\text { household assets, } \\
\text { (cars, motorcycle, } \\
\text { bicycles, } \\
\text { TV/radio). }\end{array}$ & \begin{tabular}{|c|} 
Generally have \\
necessities and \\
relatively few other \\
household assets. such \\
as TV, radio, \\
motorcycles \\
\end{tabular} & Limited assets \\
\hline Livestock & $\begin{array}{c}\text { Own dairy, } \\
\text { indigenous cows, } \\
\text { pigs, goats, } \\
\text { chicken. }\end{array}$ & $\begin{array}{l}\text { Own some dairy, } \\
\text { indigenous cows, pigs, } \\
\text { goats, chicken. }\end{array}$ & $\begin{array}{c}\text { Keep some livestock, especially dairy } \\
\text { cows/indigenous cows, pigs, goats, } \\
\text { chickens }\end{array}$ \\
\hline Land & $\begin{array}{l}\text { Relatively large } \\
\text { land owners } \\
(>2 \text { hectares) } \\
\end{array}$ & $\begin{array}{c}\text { Little land } \\
\text { (betwee1-2 hectares) }\end{array}$ & Little land ( $<1$ hectares) or landless \\
\hline Work for food & $\begin{array}{l}\text { No HH member } \\
\text { works for food }\end{array}$ & $\begin{array}{l}\text { Occasionally may sell } \\
\text { less than } 30 \text { days } \\
\text { labour/year }\end{array}$ & $\begin{array}{l}\text { Sell more than } 30 \text { days of labour per } \\
\text { year. May participate in "food-for- } \\
\text { work. Household workforce is mainly } \\
\text { comprised of children, women and } \\
\text { the elderly who command a low } \\
\text { daily wage. }\end{array}$ \\
\hline $\begin{array}{c}\text { Business/ } \\
\text { employment }\end{array}$ & $\begin{array}{c}\text { Have a good } \\
\text { business or } \\
\text { employed }\end{array}$ & None & None \\
\hline $\begin{array}{c}\text { Annual cash } \\
\text { income }\end{array}$ & >USD 700 & Between USD 400-700 & Less than USD 400 \\
\hline $\begin{array}{c}\text { Sample } \\
\text { respondents }\end{array}$ & 22 & 74 & 24 \\
\hline$\%$ & $17.3 \%$ & $14.7 \%$ & $12.5 \%$ \\
\hline
\end{tabular}

Table 2. Characteristics of each Wealth rank group 


\subsection{Characteristics of the respondents by wealth ranks}

The empirical evidence suggest that the probability of a household adopting biogas technology increases with decreasing age of the head of household, increasing household income, increasing number of cattle owned, increasing household size, male head of household and increasing cost of traditional fuels (Walekhwa et al., 2009). Also economics, material shortage, operation, and the people's acceptance are considered to be the main factors preventing the diffusion of biogas technology (Taşdemiroglu 1988).

Findings on education show the slightly well-off respondents to had relatively good education than other categories although the post secondary education was generally low across the three categories. Post secondary education such as vocational and other training is important as it creates professionals and experts including biogas experts in rural areas. The extremely poor spend very little in education hovering around $2 \%$ of household budgets (Banerjee (2007). The reason for low spending in education is that children in poor households typically attend public schools or other schools that do not charge a fee even if the education quality is poor. Poor parents are not reacting to the low quality of these schools, either by sending their children to better and more expensive schools or by putting pressure on the government to do something about quality in government schools. This partly occurs because quite often they are illiterate themselves and therefore may have a hard time recognizing that their children are not learning much (Banerjee, 2007).

Regarding family size respondents from slightly well off had small family size (3.3 persons) compared to the less poor ( 4.6 persons) and the poor (5.9 persons) (Table 3 ). This could be explained partly by the low levels of education of the poor. The less educated are more likely to start family life early than educated ones and therefore have high chances of having several children in their reproductive life time. These findings are consistent with Banerjee (2007) observation that family size is large for the extremely poor respondents.

\begin{tabular}{|l|c|c|c|}
\hline Wealth Category & Slightly Well-off & Less Poor & The Poor \\
\hline Family size (persons) & 3.3 & 4.6 & 5.9 \\
\hline Married respondents (\%) & 78.9 & 82.6 & 87.9 \\
\hline Female respondents (\%) & 22.4 & 40.7 & 35.7 \\
\hline Respondent's age (years) & 48.4 & 53.5 & 44.0 \\
\hline Education & & & \\
\hline No formal education (\%) & 0 & 1.3 & 5.1 \\
\hline Completed primary education (\%) & 50 & 59.8 & 66.7 \\
\hline Completed secondary education (\%) & 33.3 & 25.5 & 20.5 \\
\hline
\end{tabular}

Table 3. Characteristics of the respondents 


\subsection{Sources of energy for cooking}

The source of energy varied from one category to another across the three wealth ranks. Nevertheless, fuelwood dominated energy sources in all the three categories, where over $77 \%$ of the respondents were using fuelwood for cooking (Table 4), followed by biogas, very few of the respondents were using charcoal. No-one was using electricity for cooking.

The respondents were asked whether they would like to have a biogas facility in their homes or not, and almost all (96\%) said yes, they are willing to install biogas facilities.

\begin{tabular}{|l|c|c|c|c|}
\hline & The Poor & Less Poor & Slightly Well-off & Average \\
\hline Fuelwood & 89.5 & 83.3 & 60.6 & 77.8 \\
\hline Biogas & 15.9 & 18.6 & 30.3 & 21.6 \\
\hline Biogas and charcoal & 2.7 & 6.1 & 16.7 & 8.5 \\
\hline Electricity/LPG & 0 & 0 & 0 & 0 \\
\hline
\end{tabular}

Source: Survey data 2006

Table 4. Wealth Categories and Sources of Energy for Cooking (\%)

\subsection{Sources of fuelwood}

The sources of fuelwood in the district are communal forests, private forests, farms and timber residues. The distance to the fuelwood sources ranged from $1.1 \mathrm{~km}$ for the less poor and slightly well-off households and $2.25 \mathrm{~km}$ for the 'poor' categories. The average distance for all respondents was $1.40 \mathrm{~km}$. The short distance for accessing fuelwood by the slightly well off and less poor is partly because a high proportion of them have private forests near their homes. Most people in the district use fuelwood from their own planted trees. Communal land is very limited in the district.

A high proportion of the communal forests have been severely degraded which makes fuelwood not easily available. Women spend 3-4 hours looking for fuelwood. This means that households with biogas facility were saving 3-4 hours wasted in collecting fuelwood. The saved time is used for other economic activities (e.g. farming and marketing) as well as leisure (e.g. resting and listening to the news and other entertainment). On the other hand, if the use of biogas for cooking will increase the demand for fuelwood in the district may decrease which is likely to benefit the poor because most of them do not have dairy cattle for biogas plant installation.

\subsection{Awareness and cost of installing biogas facility}

Findings show that one household plant could cost USD 550- 675 with wide standard deviation suggesting a high variation for the cost of installation depending on the expertise availability and the size of the biogas facility. The size for biogas plants ranged from 6$12 \mathrm{~m}^{3}$.

A comparison across wealth ranks shows a significant difference (Table 5). The slightly welloff respondents had significantly less installation cost compared to less poor $(\mathrm{p}<5 \%)$ and the 
poor $(\mathrm{p}<2 \%)$ categories. However, there was no significant difference of cost of installation between the less poor and the poor respondents. A major explanation to this is that a high proportion of the slightly well off respondents benefited from the pilot project in 1996 when the biogas facilities were installed at half cost by the Danish volunteers. This was a strategy used to sensitise and raise awareness and demand for the biogas facilities. Unfortunately, many people from the less poor and the poor categories could not take up this opportunity because of many reasons, one of them being risk averse. They wanted to learn from others how it worked and what the advantages were to be. However, by the time they were convinced by the technology and started adopting it, the price had gone back to the market price levels. Another reason for not adopting it during the promotion period was that they had other more pressing issues than biogas, such as a need for cash to carter farming activities and paying for education and health services. Various studies have shown that poor people are always risk averse and therefore it takes time for them to adopt a new technology. Many of the studies about technology adoption conclude that the pace of adopting a new technology in developing countries has been slow among the poor. ${ }^{1}$ Feder et al., (1985) have identified factors such as aversion to risk and limited access to information as reasons that could partly explain why adoption is slow. Individual characteristics such as education, access to credit, the capacity to bear risk, availability of other inputs and access to information may play a big role in the adoption of the technology.

\begin{tabular}{|c|c|c|c|}
\hline Wealth Category & Slightly Well-off & Less Poor & \\
\hline Comparison 1 & Slightly Well-off & Less Poor & Level of significance \\
\hline & 550 & 635 & $*$ \\
& $(215)$ & The Poor & \\
\hline Comparison 2 & Less Poor & 675 & \\
\hline & 670 & $(250)$ & \multirow{2}{*}{ NS } \\
\hline Comparison 3 & Slightly Well-off & The Poor & \\
\hline & 550 & 675 & \multirow{2}{*}{$(176)$} \\
& $(250)$ & & \\
\hline
\end{tabular}

NS =not significant, ${ }^{* *}$ Significant at $\mathrm{p}<5 \%,{ }^{* * *}$ Significant at $\mathrm{p}<2 \%$

Table 5. A comparison of cost (USD) of installation across wealth ranks

\subsection{Factors constraining biogas use}

In a multiple response question, respondents were asked to mention the constraining factors towards biogas use adoption. The main factors mentioned were that the installation cost was too high $(95.8 \%)$ and lack of credit facility (95\%). Other reasons were lack of expertise $(91.7 \%)$ and inadequate water $(60 \%)$ to run the plants. Only a small proportion of $3.3 \%$ out of the 120 respondents said they do not need the facility. This may suggest that if the access to biogas is facilitated either through subsidy or access to credits many households in the district could adopt the technology. A comparison across the categories suggest that

${ }^{1}$ Giné and Klonner , 2005 
respondents from the poor and less poor were more in demand for credits and also mentioned the facility to be too costly (Table 6), suggesting a different kind of approach to induce them adopt the technology.

\begin{tabular}{|l|l|l|l|l|}
\hline Wealth Category & Slightly Well-off & Less Poor & The Poor & Total \\
\hline Too costly & 81.8 & 98.7 & 100.0 & 95.8 \\
\hline Inadequate expertise & 95.5 & 91.7 & 95.8 & 91.7 \\
\hline Inadequate water & 45.5 & 54.2 & 95.8 & 60 \\
\hline Lack of credit facilities & 86.4 & 98.6 & 100.0 & 95 \\
\hline Not aware & 9.1 & 6.9 & 20.8 & 10 \\
\hline Do not need & 9.1 & 1.4 & 4.2 & 3.3 \\
\hline
\end{tabular}

Table 6. Factors constraining biogas adoption in Rungwe district (\%)

\subsection{Energy policy and biogas technology promotion}

Tanzania's energy demand is characterised by a low per capita consumption of commercial energy (petroleum and electricity) and a high dependence on non-commercial energies, including biomass fuels in the form of firewood, charcoal and bio-waste. Renewable energy technologies currently in use in the country include improved wood-fuel stoves and charcoal production practices, biogas, windmills, and solar thermal and photovoltaics (PV). The applications of these technologies are at various stages of development in terms of demonstration and commercialization.

Tanzania has no renewable energy policy at the moment but only the general energy policy framework for all kinds of energy.

The National Energy Policy (2003) objectives are to ensure availability of reliable and affordable energy supplies and their use in a rational and sustainable manner in order to support national development goals. The National Energy Policy, therefore, aims to establish an efficient energy production, procurement, transportation, distribution and enduse systems in an environmentally sound and sustainable manner (URT, 2003). It also supports research and development of renewable energy and promotes the use of efficient biomass and end-use technologies. The main elements of the policy are:

- development of domestic energy sources and economic energy pricing,

- encouragement of private sector participation in the energy market,

- $\quad$ enhancement of energy efficiency and energy reliability

The New Electricity Act of 2008, provide room for more private sector in energy production and that increases a chance to utilize renewable energy especially on small scale targets. Markets for rural household lighting with solar home systems, biogas, and small hydropower have expanded through rural entrepreneurship, government programmes, and donor assistance, serving a number of households (Martino et al 2002).

The Act also provides roles and relations of the different actors, the ministry; regulators and operators of the sector are determined by legislation. The Ministry of Energy and Minerals (MEM) is responsible for energy development. It supervises the implementation of the energy 
policy, which is the main guidance for change, backed by legislation and regulation. The ministry also facilitates mobilisation of resources into areas where market forces fail to ensure adequate energy services. The policy put guidance for licensing operators, monitoring markets and performance; and applying any other necessary regulatory measures.

Within the Ministry of Energy and Minerals there is a Rural Energy Agency (REA) for rural electrification. The policy acknowledges that around $80 \%$ of the population has very low purchasing power and depends mainly on wood-fuel for cooking and kerosene for lighting, which have negative consequences to the environment and the quality of life, especially to the rural poor. Rural electrification is a case of long-term national interest and a prerequisite for a balanced socio-economic growth for all in Tanzania through enabling rural poor accessing sustainable clean energies.

However, energy policy has attracted criticism in different ways. Stakeholders feel that consideration of improving clean energy by rural poor needs to be on the application of appropriate technologies that are affordable, environmentally sound and well adapted to local needs as explained in the Policy. Also, while gender issues have received attention at micro level in terms of technological interventions such as cookstoves, biogas, solar cookers, and wood plantations, they have yet to be addressed in macro level policies. Women's needs for energy vary depending on whether they are in urban or rural areas, their stage of economic development and whether they are economically active. Parikh (1995) makes a plea to include gender issues in macro level energy policies such as energy investment, imports and pricing. Also there is inadequate information and data on how the ongoing and planned power sector reform can be modified to address the existing challenges, particularly with regard to electrification of the poor (Karekezi and Kimani, 2002). A study by Barnes and Floor (1996) highlights constraints towards improving clean energy in rural development and these include the widespread inefficient production and use of traditional energy sources fuelwood and charcoal which pose economic, environmental, and health threats. Also the highly uneven distribution and use of modern energy sources such as electricity, petroleum products and liquefied or compressed natural gas, pose important issues of economics, equity, and quality of life. The policy does not provide adequate strategies on overcoming these. Many developing countries including Tanzania has general energy policies pertaining to the development of electricity, oil and renewable energy subsectors for the benefit of the public and the economy. However, the absence of sharply focused, pro-rural energy policy and/or their policy instruments has been the major challenges towards the observed stagnation of some initiatives like the biogas (Habtetsion and Tsighe, 2002). The Energy Policy formulation in Tanzania takes place in the context of great uncertainty, due to mainly pressures exerted by conflicting interests (Mwandosya and Luhanga 1993).

Within the Energy Policy, biogas has received a low profile or recognition. There is no specific policy statement to explain and strategies for the promotion of biogas technology in rural Tanzania; rather everything is dumped in the category of renewable energy. Omer and Fadalla (2003) recommends that biogas technology must be encouraged, promoted, invested, implemented, and demonstrated, but especially for remote rural areas.

The main challenges facing biogas technology is inappropriate institutional structure and/or gaps in the structure, in addition to lack of corporate culture; poor incentives; and, 
poor linkages among the various stakeholders concerned in energy for rural development (Habtetsion and Tsighe, 2002). Progressive government intervention is needed to shift reform process towards a more responsible development path of renewable energy (Wamukonya, 2004). Generally speaking, the database for the context of renewable energy in Tanzania is not well documented and the renewable energy technology including biogas is still at an infant stages. So many efforts have been done by individuals of which, most of them have not been documented. The financial capital coupled with poor technology (Mwerangi, 2008) and lack of sustainable institutional framework for renewable energy developments hinders the development of biogas. This trend tallies with Uddin (1999) comment that lack of policy mechanisms, institutional development and financing exist as major barriers for Thailand

Another policy issues is lack of credits. A high proportion of the respondents in this study area indicated high cost and that there were no credit facilities in the area of study. There is also an issue of awareness and culture. A study by Mwakaje (2005) show that a large number of people who have not accessed biogas technology especially from the Muslim community have a perception that biogas is a dirty thing. However, being close to Lomwe Secondary School in Kilimanjaro Region, Tanzania and observing physically the functioning of biolatrine, many neighbour households including the Muslims were motivated to adopt the technology. The challenge was the amount of waste to feed the biodigestor and of course the cost to incur. Improving credit accessibility may have significant impact on biogas adoption in Rungwe district and Tanzania at large. Factors influencing socio-political and community acceptance are increasingly recognized as being important for understanding the apparent contradictions between general public support for renewable energy innovation and the difficult realization of specific projects (Wüstenhagen et al., 2007).

\section{Conclusion and recommendations}

Despite the over 60 years of biogas promotion in Tanzania the technology has not well developed in Rungwe district to date. This study revealed a number of issues that led to the stagnation of the technology. One, energy policy framework has put low profile of biogas in the rural energy development strategies. The technology has been dumped in the cluster of renewable energy which basically concentrates on major types of energy such as biomass (liquid biofuel and fuelwood). Today, there is a lack of adequate indigenous capacity to design, manufacture, market and distribute as well as install and maintain biogas technologies. Two, the cost of installing biogas facility of USD 550-675 is high for many of the rural poor to afford. Three, there is a tendency of risk averse among the poor to adopt new technologies including biogas. Demonstrating the technology and its related benefits might change the pace of adoption. Four, there is also an issue related to water availability. Where water is far from home creates another burden especially for women who at the end of the day they have to choose between running the biogas facilities or producing food for the family, definitely the latter will prevail. Five, the poor performance of milk marketing is linked with poor government policies, low level of management, inadequate milk markets and difficulties arising from the predominance of direct marketing (Kisusu et al., 2000. Other constraints facing dairy producers include lack of improved technology at farm level and weak institutional support (Somda et al., 2004) small size of farms and their distance from 
markets, animal health and reproductive problems and lack of good-quality animal feeds in sufficient quantities (Swai and Kurimuribo, 2011). Smallholder dairy producers often face problems of high transaction costs when it comes to the question of marketing their small quantities of milk to distant markets.

The recommendations are that the government should accommodate and institutionalize the planning of biogas technology dissemination energy in rural areas. Sensitisation should be enhanced, and support services should be provided towards optimisation of the biogas production process so that potential benefits are realized (Langeni, 2010). In this regard, addressing technical as well as non-technical factors is essential for the sustainability of biogas development and for decision making processes in the energy sector. The government should facilitate access to credit through providing information and also guarantee farmers to get credits. The government should help the farmers access milk markets through providing marketing information and selling of processed products. Modalities of the arrangements should be to link farmers to markets need to take into account socio-economic and agro-climatic diversities (Chakrabarti and Mukhopadhyay, 2009). There should be educational and awareness campaigns on biogas benefits and successes, the provision of financial and non-financial incentives to households could bolster wider biogas energy acceptance in developing countries (Walekhwa, 2009). Lastly, the government in collaboration with stakeholders should provide water near homes as strategy to facilitate biogas adoption.

\section{Acknowledgement}

The author would like to thank the Research on Poverty Alleviation (REPOA) for funding this study, without their support this work could have not been accomplished. The University of Dar es Salaam is appreciated for granting permission to undertake this study. Furthermore, thanks should go to the district authorities for facilitating this study. Last and not least, the author is grateful to the farmers for their patience and participating in this research interviews.

\section{References}

Afonja S. A (1992): "Rapid assessment methodologies: application to health and nutrition programmes in Africa", in: Scrimshaw, N. Gleason, G. (Eds), Rapid Assessment Procedures: Qualitative Methodologies for Planning and Evaluation of Health Related Programmes. (Boston: International Nutrition Foundation for Developing Countries, 1992).

Barnes D.F \& Floor W.M (1996): Rural energy in developing countries: A Challenge for Economic Development. Annual Review of Energy and the Environment. Volume. 21, 497-530

CEBITEC (2003): Centre for Excellence on Biogas Technology, Biogas Bulletin Issues N0. 001

Banerjee A. V (2007): The Economic Lives of the Poor. Journal of Economic Perspective, Volume 21 No 1, 141-16. 
Chakrabarti S \& Mukhopadhyay S (2009): Innovations for Linking Farmers to Markets: Indian Experience. Working Paper Series. Social science research network

Chambers R. (1994): "The origins \& practice of participatory rural appraisal", World Development, Volume. 22, No. 7 pp. 953-969.

Feder, G. R, Just, E., \& Zilberman, D. (1985). Adoption of agricultural innovations in developing countries: a survey, Economic Development and Cultural Change 33, 255297.

Habtetsion S \& Tsighe Z (2002): The energy sector in Eritrea-institutional and policy options for improving rural energy services. Energy Policy. Volume 30, Issues 11-12, 1107-1118

Hedegaard K, Thyø K.A \& Wenze H (2008): Life Cycle Assessment of an Advanced Bioethanol Technology in the Perspective of Constrained Biomass Availability. Environ. Sci. Technol., 2008, 42 (21), pp 7992-7999.

IRA (2005): UNDP small grant programme ex-post project study for biogas projects at Lomwe and Kaole Secondary Schools. A report prepared by the Institute of Resource Assessment (IRA). University of Dar esSalaam, Tanzania, 2005.

Karekezi S \& Kimani J (2002): Status of power sector reform in Africa: impact on the poor. Energy Policy, Volume 30, Issues 11-12,

Kisusu R. W.; Mdoe, N. S. Y.; Turuka, F. M \& Mlambiti, M. E (2000): Contribution of smallholder dairy production to food security, household income and poverty alleviation: the case of Mvumi dairy development project, Dodoma, Conference paper. Tanzanian Veterinary Journal 2000 Volume 20,. 89-99.

Langeni L. N., Mkiramweni B \& Mshoro I.B (2010): Estimating the Potential for Biogas Production and Application in Morogoro Region, Tanzania Energy and 26 environment, pp 1357-1368.

Martinot E., Chaurey A., Lew D, Moreira J.R \& Wamukonya N (2002): Renewable energy markets in developing countries. Annual Review of Energy and the Environment. Volume. 27, 309-348

Muriuki H.G.; Mwangi, D.M. \& Thorpe, W (2001): How smallholder dairy systems in Kenya contribute to food security and poverty alleviation: results of recent collaborative studies. URI: http:/ / hdl.handle.net/10568/1725

Mwakaje A.G. (2008): Dairy farming and Biogas Use in Rungwe District, Southwest Tanzania: A study of opportunities and constraints. Renewable and sustainable Energy Review. Volume 12, No 8, 2240-2252.

Mwakaje A.G. (2005): Ex-post study for UNDP-GEF Small Grant Funded Projects. The Case of Lomwe Secondary School Biogas Project. A Report for United Nation Development Programme (UNDP)-GEF.

Mwandosya M.J \& LuhangaM.L (1993): Energy and development in Tanzania: Issues and perspectives. Energy Policy, Volume 21, Issue 5, 441-453

Mwerangi I (2008): Status of renewables in Tanzania. Renewable Energy Technologies. http://renewablestechnologies.blogspot.com/2008/10/status-of-renewables-intanzania.html

Omer A.M \& Fadalla Y (2003): Biogas energy technology in Sudan. Renewable Energy, Volume 28, No 3 
Parikh J., (1995): Gender issues in energy policy. Energy Policy. Volume 23, No 9, September $1995,745-754$

Ramkumar S., Rao S.V.N \& Waldie K (2004): Dairy Cattle Rearing by Landless Rural Women in Pondicherry: A Path to Empowerment. Indian Journal of Gender Studies June 2004 volume 11 No. 2 205-222

Rutamu I (1999): Low cost biodigesters for zero grazing smallholder dairy farmers in Tanzania. Livestock Rural Dev 1999; Volume 11 No 2.

Sasse L., Kellner, C \&Kimaro, A. (1991). Improved Biogas unit for Developing countries. GATE Publication, Eschborn.

Schwengels P., ( 2009): Dairy Manure Biogas Opportunitiesin Manica Province, Mozambique. A Preliminary Assessment. Prepared for Land O' Lakes International Development Smallholder Dairy Development Programin Manica Province, Mozambique

Somda J., KamuangaM \& Tollens E (2005): Characteristics and economic viability of milk production in the smallholder farming systems in. The Gambia. gricultural Systems Volume 85, Issue 1, July 2005, pp 42-58

Swai, E.S \& Karimuribo, E.D (2011): Smallholder dairy farming in Tanzania. Current profiles and prospects for development. Source: Outlook on Agriculture, Volume 40, No 1, March 2011, pp. 21-27(7)

Taşdemiroglu E (1988): Review of the biogas technology in Turkey. Biomass. Volume 17, No 2, 1988, pp 137-148

Uddin S.N., Taplin R \& Yu X (1999): Towards a sustainable energy future-exploring current barriers and potential solutions in Thailand. Environment, Development and Sustainability. Volume 1 / 1999 - Volume 13 / 2011

URT (2010): United Republic of Tanzania. Rungwe Socio-economic profile.

URT (2008). District development plan for 2005/2006 and projections for 2006/20072007/2008; 2005.

URT (2005): Rungwe District Development Plan for 2005/2006 and projections for 2006/072007/08, 2005.

URT (2003): Tanzania Energy Policy of 2003

URT (2002). Population and housing census general report. Central Census Office, National Bureau of Statistics, President's Office Planning and Privatization. Dar es Salaam, Tanzania: Government Printer; 2002.

URT (1997): United Republic of Tanzania, Rungwe socio-economic profile.

Wamukonya N (2004): Corrigendum to "Power sector reform in developing countries: mismatched agendas". Energy Policy, 31, 1273-1289]

Walekhwa P.N., Mugisha J \& Drake L (2009): Biogas energy from family-sized digesters in Uganda: Critical factors and policy implications. Energy Policy. Volume 37, No 7, July 2009, 2754-2762.

Walshe, M.J. Grindle, J. Nell A. and M. Bachmann (1991): Dairy development in Sub-Sahara Africa: A study of issues and options. Working papers from World Bank-Technical Papers 
Wüstenhagen R, Wolsink M \& Bürer M.J (2007): Social acceptance of renewable energy innovation: An introduction to the concept. Energy Policy. Volume 35, No 5, 2683269. 


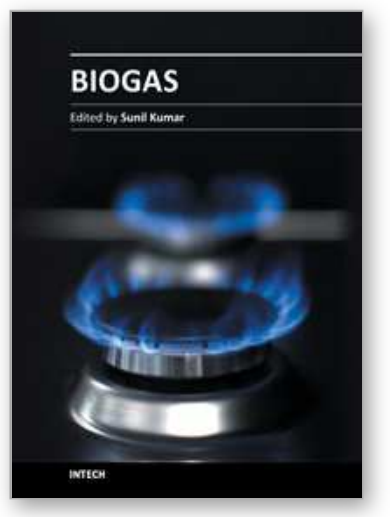

\section{Biogas}

Edited by Dr. Sunil Kumar

ISBN 978-953-51-0204-5

Hard cover, 408 pages

Publisher InTech

Published online 14, March, 2012

Published in print edition March, 2012

This book contains research on the chemistry of each step of biogas generation, along with engineering principles and practices, feasibility of biogas production in processing technologies, especially anaerobic digestion of waste and gas production system, its modeling, kinetics along with other associated aspects, utilization and purification of biogas, economy and energy issues, pipe design for biogas energy, microbiological aspects, phyto-fermentation, biogas plant constructions, assessment of ecological potential, biogas generation from sludge, rheological characterization, etc.

\section{How to reference}

In order to correctly reference this scholarly work, feel free to copy and paste the following:

Agnes Godfrey Mwakaje (2012). Dairy Farming and the Stagnated Biogas Use in Rungwe District, Tanzania: An Investigation of the Constraining Factors, Biogas, Dr. Sunil Kumar (Ed.), ISBN: 978-953-51-0204-5, InTech, Available from: http://www.intechopen.com/books/biogas/the-stagnated-biogas-use-in-rungwe-district-what-isthe-cause-

\section{INTECH}

open science | open minds

\section{InTech Europe}

University Campus STeP Ri

Slavka Krautzeka 83/A

51000 Rijeka, Croatia

Phone: +385 (51) 770447

Fax: +385 (51) 686166

www.intechopen.com

\section{InTech China}

Unit 405, Office Block, Hotel Equatorial Shanghai

No.65, Yan An Road (West), Shanghai, 200040, China

中国上海市延安西路 65 号上海国际贵都大饭店办公楼 405 单元

Phone: +86-21-62489820

Fax: +86-21-62489821 
(C) 2012 The Author(s). Licensee IntechOpen. This is an open access article distributed under the terms of the Creative Commons Attribution 3.0 License, which permits unrestricted use, distribution, and reproduction in any medium, provided the original work is properly cited. 